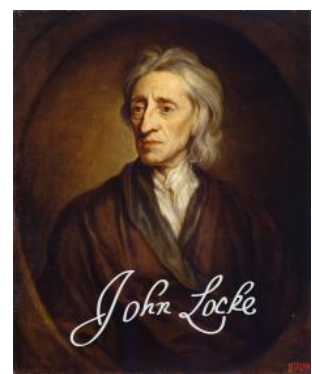

LOCKE STUDIES

Vol. 15

https://doi.org/10.5206/ls.2015.672 | ISSN: 1476-0290

Originally published: 2015

Published online: 19 FEBRUARY 2018

(C) Locke Studies, 2015

\title{
Locke, Horace, and a Syllabus Errorum
}

FELIX WALDMANN (GONVILLE \& CAIUS COLLEGE, CAMBRIDGE)

Recommended citation:

Waldmann, Felix. "Locke, Horace, and a Syllabus Errorum." Locke Studies 15 (2015): 3-29.

https://doi.org/10.5206/ls.2015.672

For more information about this article:

https://ojs.lib.uwo.ca/index.php/locke/article/view/672

Locke Studies is published by The John Locke Society.

This is an open access article published under the terms of the Creative Commons Attribution-

NonCommercial-ShareAlike 4.0 International license, which permits use, distribution and reproduction in any medium, provided the original work is properly cited and shared under the original license. 


\title{
LOCKE, HORACE, AND A SYLLABUS ERRORUM
}

\author{
FELIX WALDMANN
}

Houghton Library, Harvard University, fMS Eng 1090 (4) is an unpublished manuscript leaf in Locke's hand. ${ }^{1}$ One side of the leaf bears the direction: 'For $\mathrm{Mr}$ Awnsham Churchil / a Bookseller at the Black Swan / in Pater noster row / London.' The other side reads:

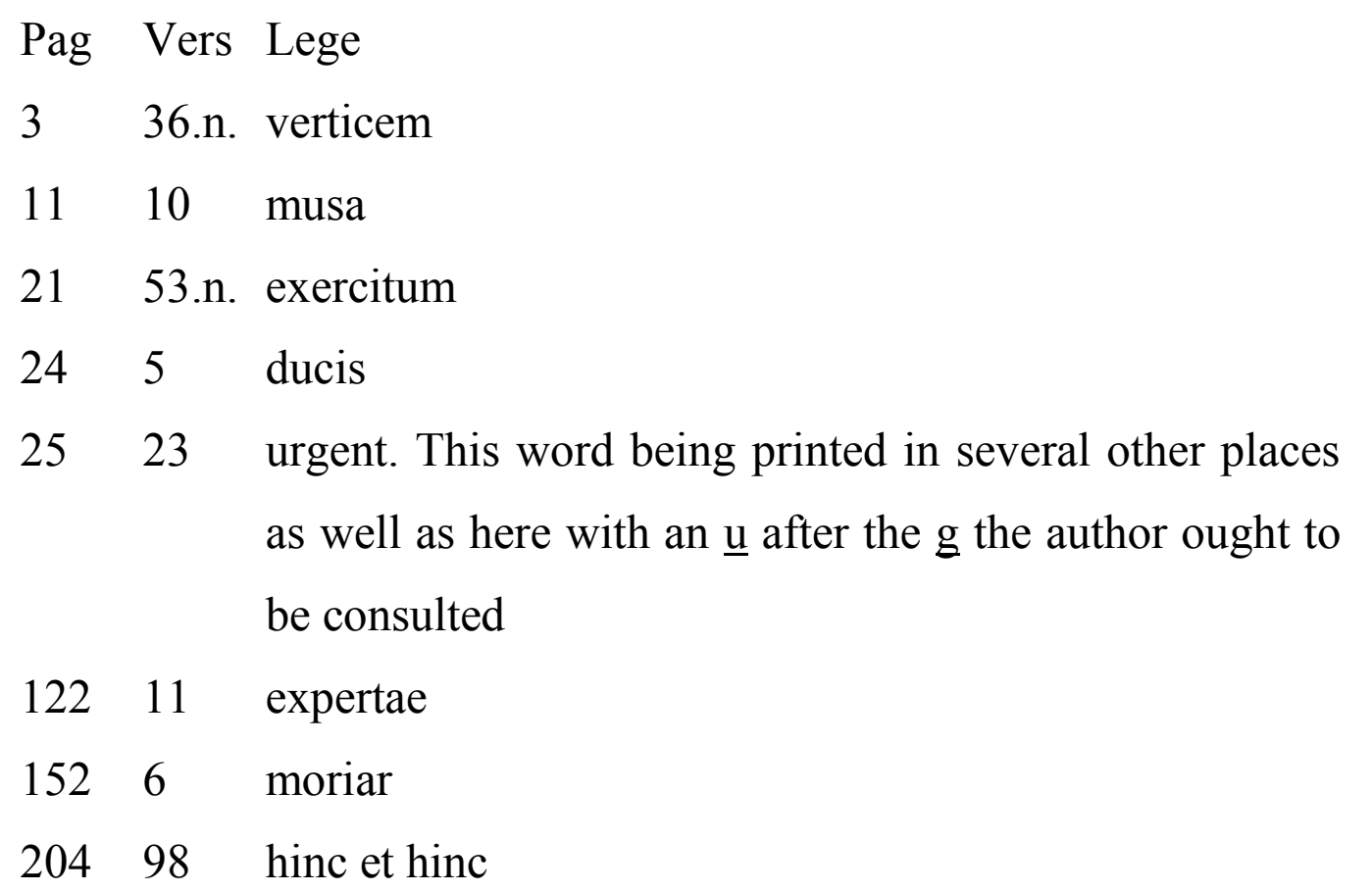

The leaf was almost certainly enclosed with a longer and unidentifiable letter to Locke's publisher Awnsham Churchill (1658-1728); its content, although obviously exiguous, permits some inferences: Locke's use of the Latin imperative 'Lege' ('read') suggests that the leaf's remarks were intended as corrections to a printed text provided by Churchill; 'the author ought to be consulted' suggests that Locke did not write the text;

${ }^{1}$ For a list of other unpublished Locke correspondence see 'Additions to de Beer's Correspondence of John Locke’, Locke Studies 15 (2015): 31-52. 
the pagination ('Pag') 204 suggests that the text was in excess of 203 pages; and the lineation ('Vers') 98 suggests that the text was continuously lineated across its pages, continuously lineated in columns, or non-columnar, not continuously lineated, and in an unusually small-point font. Guided by these presumptions, a search of Churchill's pre-1705 publications reveals the text to be a work of 1701 , edited by the schoolmaster and grammarian William Baxter (1650-1723):

Q. Horatii Flacci ecloge, una cum scholiis perpetuis, tam veteribus quam novis; prccipuè verò antiquorum grammaticorum, Helenij Acronis, Pomponiique Porphyrionis; quorum quae exstant reliquiae foedis interpolationibus purgatce nunc primum ferè integrae reponuntur: adjecit etiam, ubi visum est, \& sua, textumque ipsum plurimis locis, vel corruptum, vel turbatum restituit Willielmus Baxter

(The Eclogues of Quintus Horatius Flaccus, with continuous scholia, both ancient and modern; particularly of the ancient grammarians Helenius Acron and Pomponius Porphyrion; whose extant writings are now for the first time entirely restored, wholly cleansed of unseemly interpolations; to which William Baxter has also added or restored many passages, where corrupted or altered text has been detected).

On line thirty six of this work's third page there is a note directing the reader to an excerpt from Horace's Odes (1.18.15): 'Caecus amor sui. \& tollens vacuum plus nimio gloria verticum' [a]. Vertex is a third declension noun; its accusative singular, as Locke's correction has noted, is 'verticem' not 'verticum'. The remaining corrections appear as listed:

[b] Page 11, line 10 (Odes 1.6.10): 'Imbellisque lyrae musae potens vetat'.

[c] Page 21, line 53 note: 'Ob superatum Crassi Exercitium ipsi Romae \& Latio imminebat Parthus'.

[d] Page 24, line 5 (Odes 1.15.5): 'Nereus fata. Mala dulcis avi domum'.

[e] Page 25, line 23 (Odes 1.15.23): 'Urguent impavidi te Salaminius'.

[f] Page 122, line 11 (Odes 3.14.11): 'Jam virum experta, male ominatis'. 
[g] Page 152, line 6 (Odes 3.30.6): 'Non omnis morior, multaque pars mei'.

[h] Page 204, line 98 (Epodes 5.97): 'Vos turba vicatim \& hinc saxis petens'.

The Term Catalogues (ed. Arber (London, 1903-6), III, pp. 258-9) advertised Baxter's Horace in June 1701. On 6 October of that year John Churchill (c.1663-c.1714), Awnsham's brother and business partner, wrote to Locke, noting that he had 'delivered mr Furley [sc. Benjamin Furly (1636-1714)] a Baxters Horace as you ordered' (CJL 3005). On 18 November 1701 Furly's son Arent (d. 1712) informed Locke that he had 'sent your letter and Horace to Mr. Le Clerc [sc. Jean Le Clerc (16571736)], who doubt not but has wel received it' (CJL 3030); the price of this gift is recorded in Bodleian, MS Locke b. 1, fo. $251^{\mathrm{r}}$ : 'Sept 6 / 1 Baxter Horace sent $\mathrm{M}^{\mathrm{r}}$ leclerc / 5 [shillings]'. On 10 February 1702 Le Clerc wrote to Locke and strongly criticised the edition: 'for some time I ought to have thanked you for $\mathrm{Mr}$. Baxter's Horace, which you had the goodness to send me. The editor of that Poet has undertaken a task quite beyond his capabilities: neither the content nor the form of his edition are tolerable'. 'Locke's extant letters and manuscripts nowhere else discuss William Baxter's Horace and there is no evidence among Awnsham or John Churchill's extant letters or manuscripts to suggest a date or context for the leaf's composition. In November 1700 Awnsham Churchill had written to Locke with a 'sample of the Dictionary I got from mr Baxter to shew you', and expressed his 'fear' that Baxter would 'make a Tedious work of itt' (CJL 2805). De Beer was unable to identify this dictionary and no work fitting its description was ever published by the Churchills;

${ }^{2}$ CJL 3080: 'Il y a long-temps...que je devrois vous avoir remercié de l'Horace de Mr. Baxter, que vous avez eu la bonté de m'envoyer. L'interprete de ce Poëte a entrepris une chose fort au dessus de ses forces, et ni la matiére, ni la forme de son edition ne sont supportables'. Reviews of Baxter's edition offered a more positive assessment (Acta Eruditorum (May 1702), p. 207; Journal de Sçavans (7 Mar. 1707), pp. 141-3). For the sale of Le Clerc's copy see Jacob Wetstein and William Smith, Catalogus librorum ... Joannis Clerici (Amsterdam, 1735), p. 140 (756). 
however on the basis of Churchill's letter, it may be reasonable to conclude that he had also asked Locke to examine Baxter's Horace when the text was in preparation or in proof. ${ }^{3}$

Other indications suggest that the corrections were made by Locke only after the text's publication. Locke's booklists record a copy of Baxter's Horace (Library of John Locke, ed. John Harrison and Peter Laslett (Oxford, 1971) (LJL), 1509) and the copy is now among the Locke Library holdings at the Bodleian (Locke 9.95a). The pages noted by the leaf's corrections (pp. 3, $11,21,24,25,122,152,204)$ are free of annotation, with five new corrections marginally noted by Locke on the copy's later pages:

[i] Page 313, line 17 (Satires 2.1.17): 'Haud mihi deero'. Locke has placed a mark before 'Haud' and a caret with two diamonds $\leftrightarrow$ in the margin.

[j] Page 314, line 24 (Satires 2.1.24): 'Quid faciam?' Locke has placed a caret with two diamonds $\leftrightarrow$ in the margin before the word 'Quid'

[k] Page 338, line 163 (Satires 2.3.163): 'Hic ager'. Locke has placed a caret before 'ager' and has written an ' $æ$ ' in the margin.

[1] Page 346, line 295 (Satires 2.3.295): 'timore duorum'. Locke has placed a caret after the first ' $u$ ' in 'duorum' and has written an 'e' in the margin.

[m] Page 348, line 11 (Satires 2.4.11): 'celabitur autor. Locke has struck through the two diamonds $\leftrightarrow$ after 'autor'.

The errors identified by Locke [a]-[m] appear in fifty-nine copies of Baxter's edition which I have consulted. Seventy-two were located in total and they are tabulated in Appendix I; these copies include Baxter's own (no. 1) and a presentation copy (no. 14). In several instances, readers have also identified and amended one

3 The 'Dictionary' was likely Baxter's Glossarium antiquitatum Britannicarum (London, 1719). For the Glossarium's origins see Arthur Percival, 'William Baxter (1649-1723)', Transactions of the Honourable Society of Cymmrodorion (1957), pp. 58-86, at p. 77. The only other classical work proofread by Locke for the Churchills was his co-edition of Aesop's fables in English translation (CJL 2962, 3012, 3082, $3178,3315)$. 
or more of Locke's corrections, as shown in the table's 'Corrections' column. No copy which I have consulted bears an in-press variant at the site of the corrections nor does any copy bear an interpolated errata page. These absences must suggest that Locke's corrections were not made to the edition's proofs, unless the corrections were ignored by the Churchills, belatedly received by them, or never received at all.

This is a conclusion strengthened by the corrections' meanings:

[a] Page 3, line 36 note (Odes 1.18.15): 'Caecus amor sui. \& tollens vacuum plus nimio gloria verticum'. 'Verticum' is a genitive plural form of the third declension noun vertex ('head', 'crown'). The intended form is 'verticem', the accusative singular. Without an accusative singular noun, the accusative adjective 'vacuum' is unnecessary. The line describes 'Glory (gloria) raising (tollens) her empty head (vacuum verticem) too high (plus nimio)'.

[b] Page 11, line 10 (Odes 1.6.10): 'Imbellisque lyrae musae potens vetat'. 'Musa' (a nominative feminine singular first declension noun) is the grammatical reading. An 'imbellis lyrae' ('unwarlike lyre') is controlled by the muse. The muse and diffidence ('pudor') prevent ('vetat') the poet from diminishing the exploits of glorious Caesar: 'pudor imbellisque lyrae Musa potens vetat laudes egregii Caesaris'. If we assume that 'musae' was not simply a typographical error, we could ask whether Horace's use of a singular verb ('vetat') for plural subjects ('musa' and 'pudor') when the nearest nominative was singular ('musa...vetat') had suggested 'musae' to Baxter as an emendation. 'Potens' often combined with a genitive ('imbellis lyrae') when indicating the sphere of a subject's power ('potens musa': 'the muse has control' over the unwarlike lyre). If 'musae' was intended by Baxter as genitive addition to 'imbellis lyrae' ('of the unwarlike lyre of the muse') and 'pudor' was taken as the only subject of 'vetat' it could have resolved the discrepancy 
between a plural subject ('musa' and 'pudor') and a singular verb ('vetat'). But it would have entrained a new grammatical problem: the conjunction '-que' ('and') loses its purpose. If 'musae' was intended by Baxter as a nominative plural ('muses') it would have violated the plural subject, nearest singular noun, singular verb exception.

[c] Page 21, line 53 note: 'Ob superatum Crassi Exercitium ipsi Romae \& Latio imminebat Parthus'. This line belongs to Baxter's gloss of Odes 1.12.53: 'ille, seu Parthos Latio imminentis'. 'Exercitium' is not a possible form of the fourth declension noun 'exercitus' ('army'). The intended form is 'exercitum', the accusative singular. Without an accusative singular noun, the accusative participle 'superatum' is unnecessary. The line relates that 'The Parthian (Parthus) was threatening (imminebat) Rome and Latium itself (ipsi Romae \& Latio) on account of (ob) the defeated (superatum) army (exercitum) of Crassus (Crassi)'.

[d] Page 24, line 5 (Odes 1.15.5): 'Nereus fata. Mala dulcis avi domum'. 'Dulcis' is an adjective ('sweet', 'pleasant', 'friendly') of different meaning to the apposite verb 'ducis' (second person singular present active indicative of 'duco, ducere', 'to lead', 'to guide'). The line describes the prophecy of Nereus against Helen's abduction to Troy: 'under evil omens (mala...avi) ducis (you take) [Helen] home (domum)'.

[e] Page 25, line 23 (Odes 1.15.23): 'Urguent impavidi te Salaminius'. 'Urguent' is an alternative form of the third person plural present active indicative of the verb 'urgeo, urgere' ('to press, to push, to burden'). 'Urgeo' and its conjugations occur twenty-six times in Baxter's edition of Horace: Odes (A: 1.5.2, B: 1.15.23, C: 1.22.20, D: 1.24.6, E: 2.9.9, F: 2.10.2, G: 2.18.20, H: 3.27.57, I: 4.9.27), Epodes (J: 17.25), Satires ( $K: 1.2 .15$, L: 1.3.69, $M: 1.3 .135, N: 2.2 .64, O: 2.3 .30, P: 2.4 .77, Q: 2.5 .97, R: 2.6 .24, S:$ 2.6.29, T: 2.7.6, $U:$ 2.7.93), Epistles (V: 1.14.26, W: 2.1.260, X: 
2.2.12), De arte poetica ( $Y: 434, Z: 453){ }^{4}$ In every instance except $[A]$, Baxter has used 'urgueo' and its conjugations. When Baxter noticed the inconsistency at $[A]$, he later amended it in his own copy, inserting a superscript ' $\mathrm{x}$ ' next to the word 'urget' and a corresponding ' $\mathrm{x}$ urguet' on an interleaved facing page (Bodleian, $8^{\circ}$ Rawl. 294, p. 10). Baxter's motivations for this change are discussed below. For now it should be noted that the form 'urgueo, urguere' and its conjugations had been the subject of a longstanding controversy. A pre-eminent, early authority on Latin orthography, Velius Longus' De orthographia (c.100-200 $\mathrm{CE}$ ), had condemned the interpolation of the ' $u$ ' in 'urguere' as 'a letter defectively inserted' ('litteram vitiose insertam') and 'superfluous' ('littera videtur esse supervacua'): it was unclear to Longus how the additional ' $u$ ' ought to be pronounced ('nam quo minus unguo debeat dici apparet') and its absence from the perfect form of the verb purportedly evinced its redundancy: 'No word terminates in 'uo' either by conjunction or elision', Longus noted. 'With the result that it does not retain the same ' $u$ ' in the past tense, as we see in 'voluo, volui', 'eruo, erui' ('nullum verbum est uo terminatum sive iunctim sive solute ut non eandem u servet in praeterito, ut voluo volui, eruo erui': Grammatici latini, ed. Heinrich Keil (Leipzig, 1880) (GL), VII, p. 59). Cassiodorus repeated Longus' complaints near-verbatim in his own work on orthography (GL, VII, p. 165: 'U littera...vitiose inseritur', 'quominus unguo debeat dici evidenter apparet', 'nullum verbum est uo terminatum sive iunctim sive solute, ut non eandem u servet in praeterito, ut voluo volui') and the rule was abbreviated and reiterated by Bede (GL, VII, p. 294: 'Urgeo, non urgueo') and Alcuin (GL, VII, p. 311: 'Urgere debemus dicere, non urguere'). Notwithstanding this complaint, many manuscripts of classical texts continued to report 'urgueo' and its conjugations. Piero Valeriano's Castigationes et varietates

4 Variant readings of 'urgere' and its conjugations at Satires 2.3.39, 2.7.49 and Epistles 1.8.10 are often listed in concordances of Horace (e.g. Lane Cooper, A concordance to the works of Horace (Washington, D.C., 1916), p. 554) but these alternatives are not accepted by Baxter. 
Virgilianae lectionis (Rome, 1521), a commentary on Virgil's Aeneid, had prominently noted that 'urgueo' and its conjugations were found 'in the great part of the text's codices' (p. 82: 'in antiquis plerisque cod.'), 'even though Velius Longus calls the author defective' ('Sed...Velius Longus Auctorem appellat vitiosum'). This was a point repeated by the Antiqui, novique Latii orthographica (Tournai, 1632) of Claude Dausque (p. 335: 'Urguere cum U est...in antiquis plerisque Virgilij Codicib.'), which provided epigraphic examples of urguere's use while citing Longus', Cassiodorus', and Bede's objections. A later locus for the problem's discussion was Silius Italicus' Punica, particularly an emendation of 'urgentia' for 'ingentia' at 6.265 suggested by Caspar von Barth's Adversariorum commentariorum libri sexaginta (Frankfurt, 1624), p. 29. A collation of the Punica by Nicholaas Heinsius later found 'urguentia' to occur in a Cologne manuscript at 6.265 and this lection was printed by Heinsius' editor Arnold Drakenborch, who glossed the additional ' $u$ ' with reference to Valeriano and Dausque (Punicorum libri septemdecim (Utrecht, 1717), p. 306). This was the critical background to Egidio Forcellini's entry on urgere's orthography in his Totius latinitatis lexicon (Padua, 1771), s.v. 'urgeo', the problem's fullest early-modern discussion. Forcellini there notes that the two forms 'urgeo, urgueo' are 'read interchangeably in manuscripts and more frequently in the later period' ('promiscue leguntur in MSS...et posteriore aetate frequentius') and records that 'Piero Valeriano...,Barthius, Heinsius, Cortius [sc. Gottlieb Kortte, Dissertatio critica de usu orthographiae latinae (Leipzig, 1720-2)], Drakenborch...and others do not venture to disapprove of the practice: indeed if we see a number of manuscripts which read 'urgueo', they think this reading must be preferred' ('Pier. ad Virg. 5 Aen. 202., Barthius, Heins., Cortius, Drakenborch. ad Sil. It. et Liv....alii improbare audent: quin si multitudinem MSS. spectemus, in quibus urgueo est, praeferendum putant'). Forcellini concludes his summary by remarking that he had 'rejected neither reading' of the verb ('Neutram scriptionem damnaverim'). Locke's opinion on this matter is discussed below. 
[f] Page 122, line 11 (Odes 3.14.11): 'Jam virum experta, male ominatis'. This is a difficult and contested passage in Horace. The reading Baxter provides belongs to the lines: 'vos, o pueri et puellae jam virum expertae, male ominatis parcite verbis'. Alternative readings include 'non virum expertae, male nominatis' and 'jam virum exspectate'. 'Experta' is not given in any recension and it cannot have been Baxter's suggested emendation. 'Experta' can be the nominative or ablative or vocative feminine singular of the participle 'expertus, a, um' or it can be the participle's nominative, accusative, or vocative neuter plural. None of these declined forms can modify any of the nouns in the preceding lines ('pueri', 'puellae', 'virum'). 'Expertae' (a vocative plural participle) modifying 'puellae' (a vocative plural second declension noun) is a grammatical alternative. The line asks 'you boys, and you girls (vos, o pueri et puellae) who have now had experience of a man (puellae jam virum expertae)' to 'avoid any words of ill omen (male ominatis parcite verbis)'.

[g] Page 152, line 6 (Odes 3.30.6): 'Non omnis morior, multaque pars mei'. 'Morior' is the first person singular present active indicative of the verb 'morior, mori' ('to die'). 'Moriar' is the first person singular future active indicative of 'morior, mori'. The line ('non omnis moriar, multaque pars mei vitabit Libitinam') may be translated as 'I shall not wholly die, and a large part of me will elude the Goddess of Death'. The use of the future tense 'will elude' ('vitabit') suits - but does not require-a corresponding future tense ('moriar') in the preceding clause.

[h] Page 204, line 98 (Epodes 5.97): 'Vos turba vicatim \& hinc saxis petens'. '\& hinc' is an omission. The preferred reading ('Vos turba vicatim hinc \& hinc saxis petens') seeks to convey the omnipresence of 'a crowd (turba) attacking (petens) you (vos) with stones (saxis)'. Although 'hinc' alone ('hence', 'thence') is grammatical, it does not work as effectively in the line's context. 'Hinc \& hinc' ('on this side and on that side', 'here and there') is 
a common adverbial combination, amplifying the presence of a crowd attacking you 'here and there' (hinc \& hinc), 'from street to street' (vicatim).

[i] Page 313, line 17 (Satires 2.1.17): 'Haud mihi deero'. In Baxter's edition, two diamonds $\downarrow$ are used to signify a change of speaker in Horace's use of dialogue. In the passage amended by Locke, the character 'Trebatius' has concluded his reply to the character 'Horace'. The diamonds are used to denote the conclusion of Trebatius' speech and the commencement of Horace's response. Baxter has omitted the diamonds at this juncture, running Trebatius' lines ('Attamen \& justum poteras et scribere fortem, Scipiadam ut sapiens Lucilius') into Horace's ('Haud mihi deero, Cum res ipsa ferret...').

[j] Page 314, line 24 (Satires 2.1.24): 'Quid faciam?' An error of the type in [i] has reoccurred.

[k] Page 338, line 163 (Satires 2.3.163): 'Hic ager'. 'Ager' is a noun ('field, farm, terrain, territory') of different meaning to the noun 'aeger' ('an invalid', 'a sick person').

[1] Page 346, line 295 (Satires 2.3.295): 'Timore duorum'. 'Duorum' is an adjective ('of two') of different meaning to the noun 'deorum' (the genitive plural of the noun 'deus', 'god', 'deity').

[m] Page 348, line 11 (Satires 2.4.11): 'celabitur autor. A'. An error of the type in [i] has reoccurred, except in this instance Baxter has prematurely signalled a change of speaker.

As the corrections' meanings suggest, there can be no doubt that Baxter's errors would have been obvious to a creditable Latinist; errors [a], [d], and [f] are particularly egregious and it is unsurprising that they were detected and amended by other readers of Baxter's edition (nos. 8, 30, 36, 63, 68 in Appendix I). 
In this light, it is difficult to believe that the Churchills received Locke's corrections while Baxter's text was in proof; and it is even more difficult to believe that the corrections were passed on to Baxter after (and assuming) ${ }^{5}$ they were dispatched: Baxter's interleaved copy of his edition only corrects errors [d] and [f]; the second edition of his Horace, published posthumously by the Bowyers in 1725, amends [b], [c], [d], [f], and [g], but still does not correct [a], [e], or [h]; the third edition, enlarged by Johann Matthias Gesner (1691-1761) and published in 1752 at Leipzig, only amends [h], overlooking [a] and pointedly leaving [e] and every other instance of 'urgueo, urguere' unchanged. One cannot imagine Baxter receiving and ignoring Locke's correction to [a], even if his reaction to correction [h] might have been quibbling and his thoughts on correction [e] dismissive.

This last point - the status of correction [e] - is worth considering slightly further. As we have seen, the orthography of 'urgueo' and its conjugations had been the subject of controversy since at least Longus' De orthographia. Although it is conceivable that Locke was familiar with this debate, it appears that he was either uninterested in its concerns or without access to its textual venues: his extant publications and manuscripts nowhere discuss Longus or Latin orthography; he does not appear to have possessed any of the editions mentioned in Forcellini's discussion of 'urgere'—including Elias von Putschen's renowned

5 Only seven other letters from Locke to the Churchills are extant: three of which are retained or discarded drafts (CJL 2733, 2738, 3218), two of which appear to have been passed on to Locke's relative Peter King (1669-1734) (CJL 2927, 3521A), and one of which appears to have been dispatched but returned (CJL 3136A). The chronologically last of these is CJL 3573: the only letter of the seven now preserved outwith the Bodleian's Locke collection (BL, Stowe 748 , fo. $27^{\mathrm{r}-\mathrm{v}}$ ). Although letters from the Churchills abound among Locke's own manuscripts and feature elsewhere (Hampshire Record Office, Malmesbury Papers, 9M73/672/3; CUL, Strype Papers, Add. 4/61, 7/89, 8/126, 9/345), it appears that these were retained by their recipients rather than traded or collected by third parties from the Churchills' papers. Assuming that these lacunae signify the papers' destruction, we would be compelled to explain Houghton Library, fMS Eng 1090 (4) with reference to the manuscript's sale or donation by Locke's descendants. This would mean that Locke chose not to dispatch the manuscript or that the manuscript was dispatched but returned to his-or his descendants' - possession. 
edition of Longus, the Grammaticae latinae auctores antiqui (Hanau, 1605), cols. 2211-38; the editions of Silius Italicus' Punica which he owned record only 'ingentia' or 'urgentia' at 6.265, without reference to Heinsius' alternative; ${ }^{6}$ the Latin dictionaries and grammars which he owned make no reference to 'urguere' and its conjugations, ${ }^{7}$ and the twenty editions and one commentary of Horace which he owned are almost entirely free of the interpolated ' $u$ ' - comparisons of those works and Baxter's are made in Appendix II, showing their differences at $[a-b, d-m]$ and $[A-Z]$. If Locke was familiar with the debate over 'urguere', it was certainly not from consulting his editions of Horace; the comparisons in Appendix II make it plain that Baxter's use of the interpolated ' $u$ ' was highly eccentric. Only two of the editions reproduce it: 1498 at $[O]$ and 1499 at $[E]$ and $[F]$. In the case of 1498 , the spelling is almost certainly a typographical error: the exception is not explained by the text's editor and the passage's gloss reads 'urget' (II, p. 152). The same applies to 1499 [E], where the gloss reads 'urges' (p. 104). Indeed, of the twenty works compared, only $1499[F]$ gives the interpolated ' $u$ ' with any consistency. In other words, only one out of a possible 494 instances could be said to use the conjugations of 'urguere' designedly (a figure which excludes $L J L 1500$ and 1902). This is

${ }^{6}$ Punicorum libri XVII, ed. Hermann Busch (Basel, 1522), p. $75^{\mathrm{V}}$ (LJL 2670); De secundo bello Punico, ed. Daniel Heinsius (Leiden, 1600), p. 194 (CJL 2669, 2671)

7 Ambrogio Calepino, Dictionarium (Leiden, 1663), II, pp. 828-9 (LJL 569) and (Leiden, 1681), II, p. 845 (LJL 569a); Charles du Fresne du Cange, Glossarium (Paris, 1678), III, cols. 1371-2 (LJL 579); Elisha Coles, Dictionary (London, 1677), s.v. 'urgeo' (LJL 808a) and (London, 1679), s.v. 'urgeo' (LJL 808); Thomas Cooper, Thesaurus (London, 1573), s.v. 'urgeo' (LJL 842); Pietro Galesini, Dittionario (Venice, 1605), II, p. 494 (LJL 1207); Francis Gouldman, Dictionary (London, 1664) (LJL 1289), s.v. 'urgeo'; Ludwig Lucius, Lexicon Latino-Graecum contractius (Basel, 1638) (LJL 1822b), p. 775; Frédéric Morel, Dictionariolum (Rouen, 1669) p. 581 (LJL 2049a); Cornelis Schrevel, Lexicon (Leiden, 1670), p. 182; Gerardus Vossius, Etymologicon (Amsterdam, 1662), pp. 568-9 (LJL 3107) and (Amsterdam, 1695), p. 657 (LJL 3108); Mark Lewis, Grammar (London, 1670) (LJL 1738a) and (London, 1674) (LJL 1738); Francisco Sánchez de las Brozas, De causis (Amsterdam, 1664) (LJL 2543) and (Franeker, 1687) (LJL 2544). Eight other dictionaries owned by Locke have no lemmas for 'urgere': $L J L$ 480, 885, 961, 2086, 2227, 2227a, 2559, 2560. 
a profound level of consistency given the disparities of the editions at errors $[\mathrm{a}-\mathrm{b}, \mathrm{d}-\mathrm{m}]$, particularly when one considers their deliberate variants, such as 'nominatis' (LJL 1495, 1498, 1502-4) at Odes 3.14.11. And it is a consistency which cannot be explained by the editions' shared stemmatic relationship to a manuscript or editio princeps, since the works Locke possessed reflected a vast array of textual and manuscript traditions. Put simply, Baxter had upended previous editorial practice, suggesting that even the finest early-modern editors-like Lambin (LJL 1495, 1498) and Crucque (LJL 1499) — had silently suppressed the interpolated ' $u$ ' when collating their witnesses.

This was a suggestion later elaborated by Richard Bentley's Horace (1711). The orthography of this edition was avowedly 'based...on the standard of the Augustan Age', a standard apparently recovered 'from inscriptions, coins and the older manuscripts'. ${ }^{8}$ Words like 'vulgus', 'divum', and 'impio' would be given their ancient forms in Bentley's edition-'volgus', 'divom', 'inpio' - and accusative plurals of third declension ' $\mathrm{i}$ stem' nouns would end in 'is': 'all of which', Bentley attested ('in the best faith'), 'were found by me in the older manuscripts of Horace'. ${ }^{9}$ In obedience to this policy, Bentley rendered every instance $[A]-[Z]$ with an interpolated ' $u$ ', a choice which the finest Horace manuscript he possessed - the fragmentary 'Graevianus' (BL, Harley 2725) - partly justified: $[A]$ fo. $4^{\mathrm{v}}$ : 'urguet'; $[B]$ fo. $9^{\mathrm{v}} ;[C]$ fo. $12^{\mathrm{v}} ;[D]$ fo. $13^{\mathrm{r}} ;[E]$ fo. $23^{\mathrm{r}}$ : 'urgues'; $[G]$ fo. $28^{\mathrm{r}} ;[H]$ fo. $46^{\mathrm{v}} ;[I]$ : fo. $56^{\mathrm{r}} ;[J]$ fo. $79^{\mathrm{v}}$ : 'urguet'; $[K]$ fo. $96^{\text {r }} ;[Y]$ fo. $68^{\mathrm{r}}$ :

${ }^{8}$ Q. Horatius Flaccus, ex recensione \& cum notis atque emendationibus Richardi Bentleii (Cambridge, 1711), sig. c $3^{\mathrm{v}}$ : 'Orthographiae rationem institui ad Augusti saeculi normam, quae ex Inscriptionibus, Numis, Vetustioribusque Membranis abunde constat'. Bentley noted that his orthographic practice had followed 'others and particularly Nicholaas Heinsius' Virgil [sc. P. Virgilius Maro (Amsterdam, 1664)]' (ibid.: 'quamque $\&$ alii \& praesertim Nic. Heinsius in Virgilio suo secutus est'), an edition which had printed conjugations of 'urguere' (e.g. p. 254), among other archaicisms.

9 Q. Horatius Flaccus, ed. Bentley, sig. c3 ${ }^{\mathrm{v}}$ : 'quae omnia me in antiquioribus Flacci Codicibus reperisse fide optima testari possum'. 
'urguere'; [Z] fo. $68^{\mathrm{r}}$.

Much like his Horace, Bentley's Dissertation upon the epistles of Phalaris (London, 1699) (LJL 270) had earlier observed that ancient orthography could be deeply unstable. ${ }^{11}$ Appearing only two years after the Dissertation, Baxter's Horace was curiously free of a comparable claim. Instead, it archaised Horace's orthography without explanation, prefatory forewarning, or reference to 'antiquiores codices', all while deriving its emendations from Baxter's ingenium and the orthographically 'modern' editions of $L J L$ 1495, 1497-9, 1503, 1505-6, and 1510. Remarkably, Baxter's second edition would reject Bentley's emendations on precisely the same grounds-on the basis of editorial convention (p. 14: 'Bentleius...contra fidem omnium Librorum'), rather than manuscript collation-without once discussing Bentley's orthographic preferences. ${ }^{12}$ This was hardly an unreasonable discussion to expect. $L J L$ 1512, an edition published at Cambridge in the same year as Baxter's and quickly

10 I am grateful to the British Library for permission to consult the 'Graevianus'. For its history see $Q$. Horatius Flaccus, ed. Bentley, sigs. c2 ${ }^{\mathrm{r}-\mathrm{v}} ;$ C. O. Brink, Horace on poetry. The 'Ars Poetica' (Cambridge, 1971), pp. 9-10. Bentley's copy of Daniel Heinsius' Q. Horatii Flacii Opera (Leiden, 1612), now BL, 683.d.6, carries a number of annotations in the hand of Bentley's student Charles Cole (c.1688-1771). Cole's annotations are transcriptions of scholia written by Nicholaas Heinsius (1620-81) into a separate copy of Horace which Heinsius at one time possessed. At $[F]$ Heinsius has apparently emended the text to 'urguendo' (p. 47). The orthography of 'urgere' is otherwise undiscussed in copies of Horace bearing Bentley's ex libris or annotations (BL, 685.a.8, 679.f.7, 680.d.26, C.44.c.16), and so too his copy of Drakenborch's Punica (CUL, Adv.b.52.11).

11 Richard Bentley, A dissertation upon the epistles of Phalaris (London, 1699), p. 399: '[as] for the Orthography or way of Spelling, which is the principal variation of the Modern English from the Old; we should find as considerable a Difference between Solon's and Lysias's Spelling, if we had a sight of the Original кú $\rho \beta \varepsilon 1 \varsigma$ [or] Tables of his Laws'.

12 For examples of Baxter's criticism of Bentley see Q. Horatii Flacci Eclogae, ed. William Baxter (London, 1725), pp. 5, 7, 11-13, 20, 113, 200, 290-1. In c.1711 Bentley recorded that he had known Baxter for 'twenty years' (Christopher Wordsworth, ed., The correspondence of Richard Bentley (London, 1842), I, p. 415 (CXLVII)); his edition praised Baxter as 'doctissimus' (Satires, 2.3.157, 2.4.78) and a 'vir reconditae eruditionis' (Odes, 1.3.20). 
acquired by Locke (MS Locke f. 10, p. 486), glossed the lection 'candentes' at Odes 1.2.31 with reference to 'three of our [collated] manuscripts, and as many of the Oxonian manuscripts, which also read candentis: a synonym according to ancient orthography'. 13

In this respect, the question which must be asked is whether Locke would have disagreed with Baxter's orthography if it had been similarly explained. It is surely of some significance that almost nothing among Locke's extant manuscripts, correspondence, or publications gives an idea of his thoughts on this question. In the case of [e], it is impossible to know if Locke drew his correction from orthographic convention-his correspondence, for instance, uniformly eschews the interpolated ' $u$ ' 14 - or on the advice of textual tradition. Either way, it must also be asked why Locke's correction was so under-explained, so distant from the voluble proprieties usually demanded by the ars critica. If Locke's corrections to Baxter suggest anything, it is that his interest in the ars critica awaits fuller study, particularly in the realms of non-Biblical textual criticism, classical poetry, and 'Horatianism'. 15

13 Opera, ed. James Talbot (Cambridge, 1701), pp. 3, 241: 'Ita nostri tres MSS. \& totidem Oxonienses; vel, quod eodem redit, candentis, juxta antiquum scribendi usum'.

14 For Locke's uses of 'urgere' and its conjugations see CJL 1100, 1804, 2458. For Locke's correspondents' uses see CJL 963, 974, 1034, 1110, 1131, 1184, 1210, 1233, 1262, 1283, 1409, 1447, 1791, 1823, 1919, 2110, 2222, 2494, 2596, 2618, 2881, 3352.

15 Among other questions, it has yet to be asked why Locke was more interested in Horace than any other Latin poet; in his correspondence, for instance, invocations of Horace are nonpareil (CJL 2016, 2557 (Epistles); 623, 2458, 2739 (Satires); 1920, 2726, 3009 (Odes); 2059 (Ars poetica)). Compare Juvenal, Satires (CJL 180, 508, 571, 913, 979, 991, 1751); Ovid, Heroides (CJL 592), Metamorphoses (CJL 988); Martial, Epigrams (CJL 834, 862); Persius, Satires (CJL 5); Virgil, Eclogues (CJL 931). The twenty editions of Horace owned by Locke far exceeded the next highest: Ovid (nine editions: LJL 2154-58c), Juvenal (seven editions: LJL 1604-8b), Virgil (seven editions: LJL 3089-95). This interest in Horace may be profitably compared with the figures examined in Joanna Martindale, 'The response to Horace in the seventeenth century', University of Oxford DPhil. (1977), pp. 341-83. 
Appendix I: Copies of William Baxter's Eclogae

\begin{tabular}{|c|c|c|c|}
\hline Library & no. & Pressmark & Corrections \\
\hline \multirow{2}{*}{$\begin{array}{l}\text { Bodleian Library, } \\
\text { Oxford }\end{array}$} & 1 & $8^{\circ}$ Rawl. 294 & [d]: 'ducis' \\
\hline & & & [f]: 'expertae' \\
\hline Christ Church, Oxford & 2 & Wp.7.1 & - \\
\hline $\begin{array}{l}\text { St. John's College, } \\
\text { Oxford }\end{array}$ & 3 & $\begin{array}{l}\text { Theta.subt.up } \\
\text { per shelf.39 }\end{array}$ & - \\
\hline $\begin{array}{l}\text { Wadham College, } \\
\text { Oxford }\end{array}$ & 4 & Stack c 38.13 & [k]: 'aeger' \\
\hline \multirow[t]{2}{*}{ British Library } & 5 & 11355.bbb.19 & [f]: 'nominatis' \\
\hline & 6 & 166.m.1. & - \\
\hline $\begin{array}{l}\text { Canterbury Cathedral } \\
\text { Library }\end{array}$ & 7 & W/P-1-191 & - \\
\hline \multirow{6}{*}{$\begin{array}{l}\text { Cambridge University } \\
\text { Library }\end{array}$} & 8 & Ely.d.651 & [a]: 'verticem' \\
\hline & & & [b]: 'musa' \\
\hline & & & [f]: 'expertae' \\
\hline & & & [k]: 'aeger' \\
\hline & & & [1]: 'deorum' \\
\hline & 9 & X.3.28 & - \\
\hline $\begin{array}{l}\text { Trinity College, } \\
\text { Cambridge }\end{array}$ & 10 & NQ.9.124 & - \\
\hline Charlecote Park & 11 & & - \\
\hline Chetham's Library & 12 & $\begin{array}{l}\text { BYROM } \\
\text { 3.F.1.16 }\end{array}$ & - \\
\hline $\begin{array}{l}\text { National Library of } \\
\text { Scotland }\end{array}$ & 13 & Nha.G289 & - \\
\hline $\begin{array}{l}\text { National Library of } \\
\text { Wales }\end{array}$ & 14 & Llanelwy 816 & - \\
\hline Palace Green Library & 15 & $\begin{array}{l}\text { Bamburgh } \\
\text { L.4.52-53 }\end{array}$ & $\sim$ \\
\hline $\begin{array}{l}\text { St. Canice's Cathedral, } \\
\text { Kilkenny }\end{array}$ & 16 & & $\sim$ \\
\hline
\end{tabular}




\begin{tabular}{|c|c|c|c|}
\hline University of Melbourne & 17 & $\begin{array}{l}10 \mathrm{~A} / 26 \text { and } \\
10 \mathrm{~A} / 27\end{array}$ & [1]: 'deorum' \\
\hline $\begin{array}{l}\text { Université du Québec, } \\
\text { Montréal }\end{array}$ & 18 & YPA54 & - \\
\hline $\begin{array}{l}\text { University of Western } \\
\text { Ontario }\end{array}$ & 19 & $\begin{array}{l}\text { PA6393.A2 } \\
1701\end{array}$ & $\begin{array}{l}\text { [g]: 'moriar' } \\
{[\mathrm{h}]: \text { '\& hinc' }} \\
{[\mathrm{k}]: \text { 'aeger' }} \\
\text { [1]: 'deorum' }\end{array}$ \\
\hline Boston Public Library & 20 & 2926.24 & - \\
\hline Bowdoin College & 21 & H811 Z 1701 & - \\
\hline Brown University & 22 & $\begin{array}{l}\text { PA6393 .A2 } \\
\text { 1701a }\end{array}$ & $\sim$ \\
\hline $\begin{array}{l}\text { College of the Holy } \\
\text { Cross }\end{array}$ & 23 & $\begin{array}{l}\text { PA6393 .A2 } \\
1701\end{array}$ & - \\
\hline Columbia University & 24 & $\begin{array}{l}\text { LODGE } 1701 \\
\text { H78 }\end{array}$ & $\sim$ \\
\hline $\begin{array}{l}\text { Free Library of } \\
\text { Philadelphia }\end{array}$ & 25 & $\begin{array}{l}\text { Horace 1701, } \\
\text { M398 }\end{array}$ & - \\
\hline $\begin{array}{l}\text { General Theological } \\
\text { Seminary, New York }\end{array}$ & 26 & $\begin{array}{l}870 \mathrm{H} 935 \\
1701\end{array}$ & - \\
\hline $\begin{array}{l}\text { Henry E. Huntington } \\
\text { Library and Art Gallery }\end{array}$ & 27 & 491484 & - \\
\hline $\begin{array}{l}\text { Hobart and William } \\
\text { Smith Colleges }\end{array}$ & 28 & $\begin{array}{l}\text { S.C.C. } \\
\text { PA6393 .A2 } \\
1701 \\
\end{array}$ & - \\
\hline $\begin{array}{l}\text { Library Company of } \\
\text { Philadelphia }\end{array}$ & 29 & $\begin{array}{l}\text { O Latin Hora } \\
\text { Opera } 1701 \\
\text { Log. } 304.0\end{array}$ & - \\
\hline $\begin{array}{l}\text { New York Public } \\
\text { Library }\end{array}$ & 30 & $\begin{array}{l}\text { NTRD } \\
\text { (Baxter) } \\
\text { (Horace. Q. } \\
\text { Horatii Fl. } \\
\text { Eclogæ. } \\
\text { 1701) }\end{array}$ & $\begin{array}{l}\text { [f]: 'expertae' } \\
{[\mathrm{k}]: \text { 'aeger' }}\end{array}$ \\
\hline Northwestern University & 31 & $\begin{array}{l}\text { Horace } 1701 \\
\text { B355w }\end{array}$ & - \\
\hline Rosenlund Rare Books & 32 & & - \\
\hline
\end{tabular}


and Manuscripts,

Basking Ridge, New

Jersey

Rulon-Miller Books,

33

Saint Paul, Minnesota

University of California, 34 PA6393 .A2 -

Berkeley

$1701 \mathrm{a}$

University of California, 35 PA6393 .A2 -

Los Angeles

University of Chicago 36 PA6393.A2B [b]: 'musa'

31701

[f]: 'expertae'

[k]: 'aeger'

[1]: 'deorum'

\begin{tabular}{llll} 
& & {$[\mathrm{m}]:$} & deleted \\
\hline University of Michigan & 37 & $\mathrm{C} 21701 \mathrm{HO}$ & {$[\mathrm{i}]:$}
\end{tabular}

$[\mathrm{j}]:$ inserted

University of Nebraska- 38 PA6393 .A2 [b]: 'musa'

Lincoln 1701

\begin{tabular}{lrl}
\hline Fries Historisch en & 39 & BUMA A \\
Letterkundig Centrum, & 1153
\end{tabular}

Tresoar

Koninklijke Bibliotheek, $40 \quad$ KW 604 H 59 -

The Hague

Rijksuniversiteit $\quad 41$ RIEDEL A 88 -

Groningen

\begin{tabular}{lcll}
\hline & 42 & RIEDEL A 89 & - \\
\hline $\begin{array}{l}\text { Universiteit van } \\
\text { Amsterdam }\end{array}$ & 43 & $\begin{array}{l}\text { OTM: O 63- } \\
\text { 4996 }\end{array}$ & - \\
\hline $\begin{array}{l}\text { Bibliothèque Royale de } \\
\text { Belgique }\end{array}$ & 44 & VB 6.168 A & - \\
\hline Universiteit Gent & 45 & $\begin{array}{l}\text { BIB.CL.0004 } \\
58\end{array}$ & - \\
\hline $\begin{array}{l}\text { Kongelige Bibliotek, } \\
\text { Copenhagen }\end{array}$ & 46 & 170,236 & - \\
\hline
\end{tabular}




\begin{tabular}{|c|c|c|c|}
\hline $\begin{array}{l}\text { University Library, } \\
\text { Uppsala }\end{array}$ & 47 & $\begin{array}{l}\text { Script. Lat. } \\
\text { [Horatius] } 11\end{array}$ & - \\
\hline $\begin{array}{l}\text { Librairie au Point du } \\
\text { Jour, Geneva }\end{array}$ & 48 & & - \\
\hline $\begin{array}{l}\text { Bibliothèque Nationale } \\
\text { de France }\end{array}$ & 49 & YC-5849 & - \\
\hline & 50 & FB-6547 & $\sim$ \\
\hline $\begin{array}{l}\text { École Normale } \\
\text { Supérieure, Paris }\end{array}$ & 51 & $\mathrm{~L} \mathrm{~L} \mathrm{p} 1778^{\circ}$ & - \\
\hline $\begin{array}{l}\text { Centre Léon Robin, } \\
\text { Université Paris- } \\
\text { Sorbonne }\end{array}$ & 52 & A.Lat.A1.15 & Copy missing \\
\hline $\begin{array}{l}\text { Biblioteca Capitolare, } \\
\text { Padua }\end{array}$ & 53 & 700.X6.23 & $\sim$ \\
\hline $\begin{array}{l}\text { Biblioteca Nazionale } \\
\text { Vittorio Emanuele III, } \\
\text { Naples }\end{array}$ & 54 & $\begin{array}{l}\text { S.Q.XXIV.K. } \\
31\end{array}$ & $\begin{array}{l}\text { [f]: 'nominatis' } \\
\text { [1]: 'deorum' }\end{array}$ \\
\hline $\begin{array}{l}\text { Biblioteca Nazionale } \\
\text { Universitaria, Turin }\end{array}$ & 55 & C.SAN.29 & - \\
\hline $\begin{array}{l}\text { Biblioteca del Seminario } \\
\text { Vescovile, Padua }\end{array}$ & 56 & $\begin{array}{l}\text { 700.NERA.S } \\
\text { UP.O.6.-10 }\end{array}$ & - \\
\hline $\begin{array}{l}\text { Biblioteca Trivulziana, } \\
\text { Milan }\end{array}$ & 57 & Triv.H.1704 & - \\
\hline $\begin{array}{l}\text { Biblioteca Angelica, } \\
\text { Rome }\end{array}$ & 58 & QQ.5.41 & $\sim$ \\
\hline $\begin{array}{l}\text { Österreichische } \\
\text { Nationalbibliothek }\end{array}$ & 59 & *35.J.9 & - \\
\hline $\begin{array}{l}\text { Bayerische } \\
\text { Staatsbibliothek }\end{array}$ & 60 & A.lat.a. 321 & - \\
\hline Freie Universität Berlin & 61 & $38 / 72 / 8164(4)$ & - \\
\hline $\begin{array}{l}\text { Bibliothek der } \\
\text { Hansestadt, Lübeck }\end{array}$ & 62 & $\begin{array}{l}\text { Philol. } 8^{\circ} \\
13258\end{array}$ & $\sim$ \\
\hline $\begin{array}{l}\text { Herzog August } \\
\text { Bibliothek, Wolfenbüttel }\end{array}$ & 63 & M: Lh 950 & $\begin{array}{l}\text { [d]: 'ducis' } \\
\text { [f]: 'expertae' }\end{array}$ \\
\hline $\begin{array}{l}\text { Herzogin Anna Amalia } \\
\text { Bibliothek, Weimar }\end{array}$ & 64 & $\begin{array}{l}8^{\circ} \mathrm{XXXVIII}: \\
145\end{array}$ & $\sim$ \\
\hline
\end{tabular}




\begin{tabular}{|c|c|c|c|}
\hline $\begin{array}{l}\text { Landesbibliothek } \\
\text { Oldenburg }\end{array}$ & 65 & SPR XI 180 & [f]: 'experti' \\
\hline $\begin{array}{l}\text { Niedersächsische Staats- } \\
\text { und } \\
\text { Universitätsbibliothek, } \\
\text { Göttingen }\end{array}$ & 66 & $\begin{array}{l}8 \text { AUCT LAT } \\
\text { III, } 595\end{array}$ & $\sim$ \\
\hline $\begin{array}{l}\text { Sächsische } \\
\text { Landesbibliothek, } \\
\text { Dresden }\end{array}$ & 67 & $\begin{array}{l}\text { Lit.Rom.A.12 } \\
75\end{array}$ & - \\
\hline $\begin{array}{l}\text { Staatliche Bibliothek } \\
\text { Neuburg/Donau }\end{array}$ & 68 & $\begin{array}{l}\text { S71/8 A.ant. } \\
122\end{array}$ & [f]: 'expertae' \\
\hline $\begin{array}{l}\text { Staatsbibliothek zu } \\
\text { Berlin }\end{array}$ & 69 & 8"Wg 8384 & - \\
\hline $\begin{array}{l}\text { Thüringer Universitäts- } \\
\text { und Landesbibliothek, } \\
\text { Jena }\end{array}$ & 70 & $\begin{array}{l}8 \\
\text { Bibl.Bjelk.87 }\end{array}$ & - \\
\hline $\begin{array}{l}\text { Universitätsbibliothek } \\
\text { Leipzig }\end{array}$ & 71 & Poet.lat.512 & - \\
\hline $\begin{array}{l}\text { Universitäts- und } \\
\text { Forschungsbibliothek } \\
\text { Erfurt/Gotha }\end{array}$ & 72 & P $8^{\circ} 01660$ & $\sim$ \\
\hline $\begin{array}{l}\text { Biblioteca Central da } \\
\text { Marinha, Lisbon }\end{array}$ & 73 & $4 \mathrm{~K} 4-08$ & $\sim$ \\
\hline
\end{tabular}

A dash - in the table above signifies that the copy does not bear any form of Locke's corrections. A tilde $\sim$ signifies that the copy has not been consulted. It should be noted that no. 39 is not the copy of Baxter's edition sent by Locke to Le Clerc, although the Fries Historisch en Letterkundig Centrum does preserve a gift of this kind (Jacob van Sluis, 'A gift from John Locke to Jean Le Clerc', Locke Studies 9 (2009), 201-3). 
Appendix II: The Eclogae Corrections and Locke's Copies of Horace

LJL 1494 (BL, C.80.g.10.): Opera, ed. Nicolaus Höniger (Basel, 1580): [a] cols. 195-6; [b] cols. 73-4; [d] cols. 159-60; [e] cols. 161-2: 'Salaminius $\{$,$\} '; [f] cols. 669-70; [g] cols. 789-90; [h] cols. 971-2:$ 'hinc $\{\}$,$\& hinc'; [i] cols. 1875-6; [j] cols. 1877-8; [k] cols. 1921-2; [1]$ cols. 1927-8; [m] cols. 1965-6: 'c $\{$ a\} elabitur'; $[A]$ cols. 67-8; $[B]$ cols. 161-2; [C] cols. 223-4; [D] cols. 235-6; [E] cols. 419-20; [F] cols. 427-8; $[G]$ cols. 509-10; $[H]$ cols. 755-6; [I] cols. 873-4; $[J]$ cols. 1069-70; $[K]$ cols. 1677-8; $[L]$ cols. 1723-4; $[M]$ cols. 1725-6; [N] cols. 1891-2; [O] cols. 1915-16; [P] cols. 1967-8; [Q] cols. 1981-2; [R] cols. 1993-4; [S] cols. 1993-4; [T] cols. 2007-8; [U] cols. 2011-12; [V] cols. 2149-50; [W] cols. 2223-4; [X] cols. 2251-2; [Y] cols. 1121-2; [Z] cols. 1121-2.

LJL 1495 (BL, 655.b.7.): Opera, ed. Denis Lambin (Frankfurt, 1596): [a] pt. 1, p. 66; [b] pt. 1, p. 25; [d] pt. 1, p. 54; [e] pt. 1, p. 54; [f] pt. 1, p. 224: '\{n\}ominatis'; [g] pt. 1, p. 273: 'moriar $\{:\}$ '; [h] pt. 1, p. 353: 'hinc $\{\}$, hinc'; [i] pt. 2, p. 114; [j] pt. 2, p. 114; [k] pt. 2, p. 142: 'Hic aeger $\{:\}$ '; [1] pt. 2 , p. 145 ; [m] pt. 2, p. 175: 'au \{c\}tor'; $[A]$ pt. 1, p. 23 ; $[B]$ pt. 1, p. 54; $[C]$ pt. 1, p. $73 ;[D]$ pt. 1 , p. $76 ;[E]$ pt. 1, p. $137 ;[F]$ pt. 1, p. $140 ;[G]$ pt. 1 , p. $163 ;[H]$ pt. 1 , p. $259 ;[I]$ pt. 1 , p. $311 ;[J]$ pt. 1 , p. $395 ;[K]$ pt. 2 , p. 222 ; $[L]$ pt. 2, p. $37 ;[M]$ pt. 2 , p. $38 ;[N]$ pt. 2 , p. $124 ;[O]$ pt. 2 , p. $140 ;[P]$ pt. 2 , p. $177 ;[Q]$ pt. 2 , p. $188 ;[R]$ pt. 2, p. $201 ;[S]$ pt. 2 , p. $201 ;[T]$ pt. 2 , p. 213 ; $[U]$ pt. 2 , p. $215 ;[V]$ pt. 2 , p. 307 ; $[W]$ pt. 2 , p. 366 ; $[X]$ pt. 2 , p. 389 ; $[Y]$ pt. 2, p. 421; [Z] pt. 2, p. 421.

LJL 1496 (St John's College, Oxford, Lambda 1.15): Poemata, ed. Pierre Gaultier Chabot (Basel, 1594): [a] pt. 1, p. 101; [b] pt. 1, p. 49; [d] pt. 1, p. 89: 'fata $\{:\}$ '; [e] pt. 1, p. 90; [f] pt. 1, p. 295: 'male $\{\mathrm{n}\}$ ominatis'; [g] pt. 1, p. 340 ; [h] pt. 1, p. 418; [i] pt. 2, p. 594; [j] pt. 2, p. 594; [k] pt. 2, p. 624: 'Hic aeger\{:\}'; [1] pt. 2, p. 626; [m] pt. 2, p. 656: 'au\{c\}tor'; [A] pt. 1, p. 46; $[B]$ pt. 1, p. 90; $[C]$ pt. 1, p. 113; [D] pt. 1, p. 118; $[E]$ pt. 1, p. $190 ;[F]$ pt. 1 , p. $193 ;[G]$ pt. 1 , p. $227 ;[H]$ pt. 1 , p. $328 ;[I]$ pt. 1 , p. $373 ;[J]$ pt. 1 , p. $458 ;[K]$ pt. 2 , p. $487 ;[L]$ pt. 2 , p. $508 ;[M]$ pt. 2 , p. $508 ;[N]$ pt. 2 , p. 606 ; $[O]$ pt. 2 , p. 623 ; $[P]$ pt. 2 , p. 657 ; $[Q]$ pt. 2 , p. $668 ;[R]$ pt. 2 , p. $681 ;[S]$ pt. 2 , p. $681 ;[T]$ pt. 2 , p. $691 ;[U]$ pt. 2 , p. $692 ;[V]$ pt. 3, p. $806 ;[W]$ pt. 3 , p. $861 ;[X]$ pt. 3, p. $884 ;[Y]$ pt. 3, p. 917 ; [Z] pt. 3, p. 917.

LJL 1497 (BL, G.9515.): Q. Horatius Flaccus, ed. Lieven van der Beken (Antwerp, 1608): [a] p. 67; [b] p. 25; [d] p. 56; [e] p. 56; [f] p. 228; [g] p. 274; [h] p. 350 ; [i] p. 513; [j] p. 513; [k] p. 540; [1] p. 543; [m] p. 567: 
'au $\{$ c\}tor'; $[A]$ p. $23 ;[B]$ p. $56 ;[C]$ p. $77 ;[D]$ p. $80 ;[E]$ p. $146 ;[F]$ p. $148 ;$ $[G]$ p. $170 ;[H]$ p. $263 ;[I]$ p. $309 ;[J]$ p. $389 ;[K]$ p. $422 ;[L]$ p. $437 ;[M]$ p. 439; $[N]$ p. 523; $[O]$ p. 537; $[P]$ p. 569; $[Q]$ p. 579; $[R]$ p. 587; $[S]$ p. 587; $[T]$ p. $599 ;[U]$ p. $601 ;[V]$ p. $678 ;[W]$ p. $721 ;[X]$ p. $739 ;[Y]$ p. $782 ;[Z]$ p. 782.

LJL 1498 (BL, C.80.g.11.): Opera, eds. Denis Lambin, Théodore Marcile, et al. (Paris, 1604): [a] I, p. 67; [b] I, p. 25; [d] I, p. 55; [e] I, p. 55; [f] I, p. 211: ' $\{$ n $\}$ ominatis'; [g] I, p. 252: 'moriar $\{:\}$ '; [h] I, p. 322: 'vos turba $\{\mathrm{m}\}$ hinc $\{\}$,$\& hinc'; [i] II, p. 115; [j] II, p. 115; [k] II, p. 143: 'Hic aeger \{:\}$ '; [1] II, p. 146; [m] II, p. 177: 'au\{c\}tor'; [A] I, p. 23; [B] I, p. 55; [C] I, p. 75; [D] I, p. 78; [E] I, p. 136; [F] I, p. 138; [G] I, p. 159; [H] I, p. 240; [I] I, p. $285 ;[J]$ I, p. $362 ;[K]$ II, p. 19; [L] II, p. 34; [M] II, p. 36; [N] II, p. 125; $[O]$ II, p.141: 'urguet'; $[P]$ II, p. 178; $[Q]$ II, p. 189; $[R]$ II, p. 203; [S] II, p. 203; [T] II, p. 215; [U] II, p. 217; [V] II, p. 311; [W] II, p. 366; [X] II, p. 387; [Y] II, p. 418; [Z] II, p. 418.

LJL 1499 (BL, 655.b.8.): Q. Horatius Flaccus, ed. Jacques De Crucque (Leiden, 1611): [a] p. 47; [b] p. 20; [d] p. 40; [e] p. 40; [f] p. 176: 'male $\{\mathrm{n}\}$ ominatis'; [g] p. 210; [h] p. 261: 'hinc\{,\} \& hinc'; [i] p. 406; [j] p. 406; [k] p. 430: 'Hic aeger $\{:\}$ '; [1] p. 432; [m] p. 457: 'au\{c\}tor'; [A] p. 18; [B] p. 40; $[C]$ p. 52; $[D]$ p. 55 ; $[E]$ p. 104: 'urgues'; $[F]$ p. 106: 'urguendo'; $[G]$ p. $118 ;[H]$ p. 202; $[I]$ p. $234 ;[J]$ p. $293 ;[K]$ p. $315 ;[L]$ p. $331 ;[M]$ p. 332 ; $[N]$ p. $415 ;[O]$ p. $429 ;[P]$ p. $458 ;[Q]$ p. $473 ;[R]$ p. $481 ;[S]$ p. $481 ;[T]$ p. $491 ;[U]$ p. 492; [V] p. 558; [W] p. 592; [X] p. 605; [Y] p. 621; [Z] p. 621.

LJL 1500: Poemata (Paris, 1640) is an exceedingly rare $24^{\circ}$ edition based upon the 1606 commentary of John Bond (c.1550-1612). Only one copy appears to be extant: Bibliothèque nationale de France, FB-6542. This copy is shelved in the Château de Fontainebleau and I have not been able to consult it. Bibliothèque nationale de France, YV-5818 and SUNY Buffalo PA6393 .A2 1640 appear to be copies of a $16^{\circ}$ edition of Bond's commentary published at Paris in 1640 and should not be confused with LJL 1500.

LJL 1501 (BL, 11386.b.7.): Q. Horatius Flaccus, eds. John Bond and Cornelis Schrevel (Leiden, 1653): [a] p. 53; [b] p. 22; [d] p. 43; [e] p. 45; [f] p. 197; [g] p. 242: 'moriar $\{:\}$ '; [h] p. 325: 'vicatim $\{$,$\} hinc \& hinc saxis$ petens $\{$,$\} '; [i] p. 491; [j] p. 491; [k] p. 533; [1] p. 547; [m] p. 552:$ 'au \{c\}tor'; $[A]$ p. $19 ;[B]$ p. $45 ;[C]$ p. $59 ;[D]$ p. $61 ;[E]$ p. $114 ;[F]$ p. 116 ; $[G]$ p. $140 ;[H]$ p. $233 ;[I]$ p. $280 ;[J]$ p. $363 ;[K]$ p. $392 ;[L]$ p. $413 ;[M]$ p. 
419; [N] p. 507; [O] p. 520; [P] p. 561; [Q] p. 573; [R] p. 578; [S] p. 579; $[T]$ p. $589 ;[U]$ p. $598 ;[V]$ p. $684 ;[W]$ p. $756 ;[X]$ p. $760 ;[Y]$ p. $834 ;[Z]$ p. 836.

LJL 1502 (BL, 685.a.7.): Q. Horatius Flaccus, ed. Daniel Heinsius (Leiden, 1629): [a] p. 19; [b] p. 8; [d] p. 15: 'fata $\{:\}$ '; [e] p. 16; [f] p. 65: ' $\{$ n $\}$ ominatis'; [g] p. 81: 'moriar $\{:\}$ '; [h] p. 106: 'vicatim $\{$,$\} hinc \& hinc$ saxis petens $\{$,$\} '; [i] p. 152; [j] p. 152; [k] p. 163; [1] p. 166; [m] p. 168:$ 'au\{c\}tor'; $[A]$ p. $8 ;[B]$ p. $16 ;[C]$ p. $21 ;[D]$ p. $21 ;[E]$ p. $39 ;[F]$ p. $39 ;[G]$ p. $47 ;[H]$ p. $77 ;[I]$ p. $92 ;[J]$ p. $117 ;[K]$ p. $126 ;[L]$ p. $131 ;[M]$ p. $133 ;[N]$ p. 156; [O] p. 159; [P] p. 170; [Q] p. 173; $[R]$ p. 174; $[S]$ p. 174; $[T]$ p. 177; $[U]$ p. 179; [V] p. 201; [W] p. 219; [X] p. 220; [Y] p. 238; [Z] p. 239.

LJL 1503 (BL, 1002.g.3.): Opera, ed. Louis Desprez (London, 1694): [a] p. 52; [b] p. 18; [d] p. 41; [e] p. 43: 'Salaminius $\{$,$\} '; [f] p. 205:$ ' $\{$ n\}ominatis'; [g] p. 243; [h] p. 307; [i] p. 454; [j] p. 454; [k] p. 488; [1] p. 501; $[\mathrm{m}]$ p. 505 : 'au $\{$ c $\}$ tor'; $[A]$ p. $15 ;[B]$ p. $43 ;[C]$ p. $61 ;[D]$ p. $64 ;[E]$ p. $125 ;[F]$ p. $127 ;[G]$ p. $152 ;[H]$ p. $235 ;[I]$ p. $271 ;[J]$ p. $333 ;[K]$ p. 364 ; $[L]$ p. $381 ;[M]$ p. $386 ;[N]$ p. $468 ;[O]$ p. $479 ;[P]$ p. $513 ;[Q]$ p. $522 ;[R]$ p. 526; [S] p. 527; [T] p. 534; [U] p. 541; [V] p. 610; [W] p. 661; [X] p. 662; $[Y]$ p. $701 ;[Z]$ p. 702.

LJL 1504 (BL, 11386.aaa.7.): Opera, ed. Pierre de Rodelle (Toulouse, 1683): [a] pp. 40-1; [b] p. 15; [d] p. 32: 'Nereus fata\{:\} Mala'; [e] p. 33; [f] p. 151: ' $\{\mathrm{n}\}$ ominatis'; [g] p. 213: 'moriar $\{:\}$ '; [h] p. 244: 'vicatim $\{$, hinc $\{\}$,$\& hinc'; [i] p. 344; [j] p. 345 ;[\mathrm{k}]$ p. 371; [1] p. 381; [m] p. 385: 'au \{c\}tor'; $[A]$ not printed; $[B]$ p. $33 ;[C]$ p. $45 ;[D]$ p. $47 ;[E]$ p. $88 ;[F]$ p. $89 ;[G]$ p. $107 ;[H]$ p. $175 ;[I]$ p. $212 ;[J]$ p. $261 ;[K]$ p. $283 ;[L]$ p. $289 ;[M]$ p. $294 ;[N]$ p. $354 ;[O]$ p. $362 ;[P]$ p. $389 ;[Q]$ p. $398 ;[R]$ p. $401 ;[S]$ p. 402 ; $[T]$ p. 408; [U] p. 414; [V] p. 473; [W] p. 526; [X] p. 528; [Y] p. 583; [Z] p. 585 .

LJL 1505 (Bodleian, $8^{\circ}$ L 32-41 Linc.): Les oeuvres, ed. André Dacier (Paris, 1691): [a] I, p. 240; [b] I, p. 94; [d] I, p. 204; [e] I, p. 206; [f] III, p. 268; [g] III, p. 498: 'moriar\{:\}'; [h]: V, p. 106; [i] VII, p. 4; [j] VII, p. 6; [k] VII, p. 172; [1] VII, p. 196; [m] VII, p. 332: 'Au \{c\}tor'; [A] I, p. 86; [B] I, p. 206; [C] I, p. 270; [D] I, p. 282; [E] II, p. 176; [F] II, p. 192; [G] II, p. 340; [H] III, p. 434; [I] IV, p. 238; [J] V, p. 336; [K] VI, p. 86; [L] VI, p. 192; [M] VI, p. 204; [N] VII, p. 68; [O] VII, p. 150; [P] VII, p. 342; [Q] VII, p. 392; [R] VII, p. 436; [S] VII, p. 436; [T] VII, p. 488; [U] VII, p. 
502; [V] VIII, p. 534; [W] IX, p. 304; [X] IX, p. 442; [Y] X, p. 72; [Z] X, p. 76.

LJL 1506 (Bodleian, Locke 6.184b): Q. Horatius Flaccus, ed. Jan Rutgers (Utrecht, 1699): [a] p. 16; [b] p. 6; [d] p. 13; [e] p. 14; [f] p. 62; [g] p. 76: 'moriar\{:\}'; [h] p. 101: 'hinc\{,\} \& hinc'; [i] p. 144; [j] p. 144; [k] p. 154 'Hic aeger $\{:\}$ '; [1] p. 158; [m] p. 159: 'au \{c\}tor'; [A] I, p. 86; [B] I, p. 206; $[C]$ I, p. 270; [D] I, p. 282; [E] II, p. 176; [F] II, p. 192; [G] II, p. 340; $[H]$ III, p. 434; [I] IV, p. 238; [J] V, p. 336; [K] VI, p. 86; [L] VI, p. 192; [M] VI, p. 204; [N] VII, p. 68; [O] VII, p. 150; [P] VII, p. 342; [Q] VII, p. 392; $[R]$ VII, p. 436; [S] VII, p. 436; [T] VII, p. 488; [U] VII, p. 502; [V] VIII, p. 534; [W] IX, p. 304; [X] IX, p. 442; [Y] X, p. 72; [Z] X, p. 76.

LJL 1507/1512 (BL, 166.k.2.): Opera, ed. James Talbot (Cambridge, 1701): [a] p. 17; [b] p. 6; [d] p. 14; [e] p. 14; [f] p. 65; [g] p. 213: 'moriar $\{;\}$ multaque'; [h] p. 105: 'vicatim $\{$,$\} hinc \& hinc saxis petens \{$,$\} ';$ [i] p. 150; [j] p. 150; [k] p. 159; [1] p. 163; [m] p. 164: 'au \{c\}tor'; [A] p. 6; $[B]$ p. $14 ;[C]$ p. $19 ;[D]$ p. $20 ;[E]$ p. $38 ;[F]$ p. $38 ;[G]$ p. $46 ;[H]$ p. $76 ;[I]$ p. $91 ;[J$ p. $116 ;[K]$ p. $125 ;[L]$ p. $130 ;[M]$ p. $131 ;[N]$ p. $153 ;[O]$ p. 156 ; $[P]$ p. $166 ;[Q]$ p. $169 ;[R]$ p. $170 ;[S]$ p. $170 ;[T]$ p. $173 ;[U]$ p. $175 ;[V]$ p. $197 ;[W]$ p. 216; $[X]$ p. 216; [Y] p. 234; [Z] p. 235.

LJL 1508: Harrison and Laslett were unable to identify this work from the description provided by Locke: '[Opera.] $8^{\circ}$. Ant: [1] 552 7/148b'. I believe I have identified it. ${ }^{16}$ (Bodleian, Arch.Jur. III. 9): Q. Horatii Flacci Venusini...Poemata omnia, doctissimis scholijs illustrata, ed. Pietro Baldi del Riccio (Crinito) (Antwerp, 1552): [a] sig. B6 ${ }^{\mathrm{r}}$ : ' $\{$ At $\}$ tollens'; [b] sig.

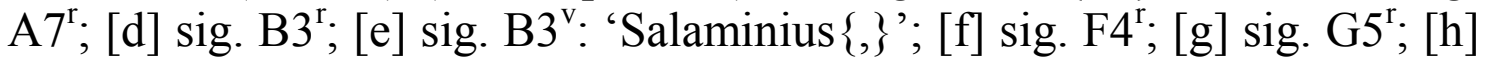
sig. I4 ${ }^{\mathrm{v}}$ : 'hinc $\{\}$,$\& hinc'; [i] sig. Q4 { }^{\mathrm{r}}$; [j] sig. Q4 ${ }^{\mathrm{r}}$; [k] sig. R1': 'Hic aeger $\{,\}^{\prime} ;[1]$ sig. R3 $3^{\mathrm{v}} ;[\mathrm{m}]$ sig. $\mathrm{R} 4^{\mathrm{v}} ;[A]$ sig. $\mathrm{A} 6^{\mathrm{v}} ;[B]$ sig. $\mathrm{B} 4^{\mathrm{v}} ;[C]$ sig. $\mathrm{B} 7^{\mathrm{v}}$; $[D]$ sig. $\mathrm{B} 8^{\mathrm{r}} ;[E]$ sig. $\mathrm{D}^{\mathrm{r}} ;[F]$ sig. $3^{\mathrm{v}} ;[G]$ sig. $\mathrm{D} 8^{\mathrm{v}} ;[H]$ sig. $\mathrm{G} 3^{\mathrm{r}} ;[I]$ sig. $\mathrm{H}^{\mathrm{r}} ;[J]$ sig. K3${ }^{\mathrm{v}} ;[K]$ sig. $5^{\mathrm{v}} ;[L]$ sig. $8^{\mathrm{v}} ;[M]$ sig. $\mathrm{P}^{\mathrm{v}} ;[N]$ sig. $6^{\mathrm{r}} ;[O]$ sig. $7^{\mathrm{v}} ;[P]$ sig. $\mathrm{R} 5^{\mathrm{v}} ;[Q]$ sig. $\mathrm{R}^{\mathrm{r}} ;[R]$ sig. ${ }^{\mathrm{r}}{ }^{\mathrm{r}} ;[S]$ sig. $\mathrm{R} 8^{\mathrm{r}} ;[T]$ sig. $\mathrm{S} 1^{\mathrm{v}} ;$ $[U]$ sig. S2 ${ }^{\mathrm{v}} ;[V]$ sig. $\mathrm{M}^{\mathrm{r}}$; $[W]$ sig. $\mathrm{N}^{\mathrm{v}} ;[X]$ sig. $\mathrm{N}^{\mathrm{r}} ;[Y]$ sig. $\mathrm{T} 4^{\mathrm{r}} ;[Z]$ sig. $\mathrm{T} 4^{\mathrm{r}}$.

16 For this identification see Felix Waldmann, 'The Library of John Locke: additions, corrigenda, and a conspectus of pressmarks', Bodleian Library Record 26 (2013), 36-58. I there incorrectly state that a copy of LJL 1508 is unavailable in the United Kingdom. Two typographical errors in that article should also be amended: $p$. 45, 1. 26: Evangeliorum; p. 46, 1. 24: Animadversiones. 
LJL 1509 (Bodleian, Locke 9.95a): Baxter's edition.

LJL 1510 (BL, 237.e.22.): Poemata, ed. Henri Estienne (Paris, 1575): [a] p. 18; [b] p. 7; [d] p. 15; [e] p. 15; [f] p. 72; [g] p. 89: 'moriar $\{:\}$ multaque'; [h] p. 119; [i] p. 35 ; [i] p. $35 ;[\mathrm{k}]$ p. $46 ;[1]$ p. $50 ;$ [m] p. $52 ;[A]$ p. $6 ;[B]$ p. $15 ;[C]$ p. $21 ;[D]$ p. $22 ;[E]$ p. $41 ;[F]$ p. $42 ;[G]$ p. $51 ;[H]$ p. $85 ;[I]$ p. $103 ;[J]$ p. $131 ;[K]$ p. $5 ;[L]$ p. $11 ;[M]$ p. $13 ;[N]$ p. $39 ;[O]$ p. 42 ; $[P]$ p. $54 ;[Q]$ p. $57 ;[R]$ p. $59 ;[S]$ p. $59 ;[T]$ p. $62 ;[U]$ p. $64 ;[V]$ p. $90 ;[W]$ p. $112 ;[X]$ p. 113; [Y] p. 133; [Z] p. 134.

LJL 1511 (BL, 1002.c.14.): Oper[a], ed. Eduard van Zurck (Haarlem, [1696]): [a] I, p. 43; [b] I, p. 17; [d] I, p. 35; [e] I, p. 37; [f] I, p. 179: '\{n\}ominatis'; [g] I, p. 213: 'pars mei \{,\}; [h] I, p. 271: 'hinc $\{\}$,$\& hinc'; [i]$ II, p. 379; [j] II, p. 380; [k] II, p. 404; [1] II, p. 414; [m] II, p. 417: 'Au\{c\}tor'; $[A]$ I, p. 15; $[B]$ I, p. 37; $[C]$ I, p. 49; [D] I, p. 51; [E] I, p. 105; $[F]$ I, p. 106; [G] I, p. 131; [H] I, p. 205; [I] I, p. 240; [J] I, p. 296; [K] II, p. 315; [L] II, p. 328; [M] II, p. 333; [N] II, p. 389; [O] II, p. 396; [P] II, p. 421; [Q] II, p. 429; [R] II, p. 431; [S] II, p. 432; [T] II, p. 438; [U] II, p. 443; [V] II, p. 503; [W] II, p. 549; [X] II, p. 551; [Y] II, p. 600; [Z] II, p. 601 .

LJL 1512a (BL, 11388.b.17.): Poemata, ed. Jan Minelli (Rotterdam, 1677): [a] p. 43; [b] p. 15; [d] p. 35: 'fata. \{Multa\} ducis'; [e] p. 36; [f] p. 155; [g] p. 187; [h] p. 240: 'vicatim $\{$,$\} hinc \& hinc saxis petens \{$,$\} '; [i] p. 337; [j]$ p. $338 ;[\mathrm{k}]$ p. $363 ;[1]$ p. $372 ;[\mathrm{m}]$ p. $375 ;[A]$ p. $13 ;[B]$ p. $36 ;[C]$ p. $48 ;[D]$ p. $50 ;[E]$ p. $93 ;[F]$ p. $94 ;[G]$ p. $113 ;[H]$ p. $180 ;[I]$ p. $212 ;[J]$ p. $261 ;[K]$ p. 278; $[L]$ p. 290; $[M]$ p. $293 ;[N]$ p. $348 ;[O]$ p. $355 ;[P]$ p. $379 ;[Q]$ p. 387; [R] p. $360 ;[S]$ p. $360 ;[T]$ p. $396 ;[U]$ p. $402 ;[V]$ p. $462 ;[W]$ p. 510 ; $[X]$ p. $512 ;[Y]$ p. $561 ;[Z]$ p. 562.

LJL 1902 (Bodleian, Locke 14.47 (1)): Opera, ed. Théodore Marcile (Paris, 1604). $[F]$ p. $45 ;[J$ p. $78 ;[N]$ p. $101 ;[R]$ p. $110 ;[S]$ p. $110 ;[X]$ p. $143 ;[Y]$ p. 161.

MS Locke b. 2, fo. $36^{\mathrm{r}}$ records two editions of Horace purchased by Locke at the sale of the libraries of Dr. William Outram (1626-79) and Dr. Thomas Gataker (1574-1654) on 12 December 1681: '203 Horatius 66' and ' 209 Chabotii in Horatium 89'. The printed auction catalogue of the sale lists the first volume as ' $Q$. Horatii Flacii Poemata Jo. Bond. Comment. Lond. 1666' and the second as 'P. Gault. Chabotii Expositio Analytica in Q. Horatium. Basil. 1589' (Catalogus librorum...Gulielmi 
Outrami...Thomae Gatakeri (London, 1681) [ESTC, R15702], p. 26 (lots 203, 209)). Neither edition is listed in $L J L{ }^{17}$

Poema[ta], ed. Pierre Gaultier Chabot (Basel, 1589) (Cambridge University Library [CUL], X.10.40): [a] p. 44; [b] p. 19; [d] p. 37; [e] p. 38; [f] p. 147; [g] p. 177: 'moriar\{:\}'; [h] p. 230; [i] p. 338; [j] p. 339; [k] p. 366: 'Hic aeger $\{:\}$ '; [1] p. $374 ;[\mathrm{m}]$ p. $377 ;[A]$ p. 18 ; [B] p. 38; [C] p. 50; $[D]$ p. $53 ;[E]$ p. $91 ;[F]$ p. $92 ;[G]$ p. $109 ;[H]$ p. $170 ;[I]$ p. $202 ;[J]$ p. 256 ; $[K]$ p. $275 ;[L]$ p. $288 ;[M]$ p. $293 ;[N]$ p. $349 ;[O]$ p. $357 ;[P]$ p. $382 ;[Q]$ p. $390 ;[R]$ p. 394; $[S]$ p. $395 ;[T]$ p. 400 ; [U] p. $405 ;[V]$ p. 462 ; [W] p. 512 ; $[X]$ p. 514; [Y] p. 563; [Z] p. 565.

Poemata, ed. John Bond (London, 1606) (Sterling Memorial Library, Yale University, Gnh6 a606) [ESTC, S117865]: [a] p. 23; [b] p. 8; [d] p. 18; [e] p. 19; [f] p. 87; [g] p. 106: 'moriar $\{:\} '$; [h] p. 139; [i] p. 196; [j] p. 197; [k] p. $209 ;[1]$ p. $213 ;[\mathrm{m}]$ p. $215 ;[A]$ p. $7 ;[B]$ p. $19 ;[C]$ p. $26 ;[D]$ p. $27 ;[E]$ p. $51 ;[F]$ p. $52 ;[G]$ p. $62 ;[H]$ p. $102 ;[I]$ p. $121 ;[J]$ p. $153 ;[K]$ p. $164 ;[L]$ p. $170 ;[M]$ p. $172 ;[N]$ p. $201 ;[O]$ p. $205 ;[P]$ p. 217 ; $[Q]$ p. $221 ;[R]$ p. 223 ; $[S]$ p. $223 ;[T]$ p. $227 ;[U]$ p. $230 ;[V]$ p. $260 ;[W]$ p. $286 ;[X]$ p. $288 ;[Y]$ p. 311; [Z] p. 312. Poemata, ed. John Bond (London, 1660) (CUL, X.11.46) [ESTC, R233416]: [a] p. 23; [b] p. 8; [d] p. 18; [e] p. 19; [f] p. 87; [g] p. 106; [h] p. 139; [i] p. 196; [j] p. 197; [k] p. 209; [1] p. 213; [m] p. 215; [A] p. $7 ;[B]$ p. $19 ;[C]$ p. $26 ;[D]$ p. $27 ;[E]$ p. $51 ;[F]$ p. $52 ;[G]$ p. $62 ;[H]$ p. $102 ;[I]$ p. $121 ;[J]$ p. $153 ;[K]$ p. $164 ;[L]$ p. $170 ;[M]$ p. $172 ;[N]$ p. 201 ; $[O]$ p. $205 ;[P]$ p. $217 ;[Q]$ p. $221 ;[R]$ p. $223 ;[S]$ p. $223 ;[T]$ p. $226 ;[U]$ p. 230; [V] p. 260; [W] p. 286; [X] p. 288; [Y] p. 311; [Z] p. 312.

In the comparisons above, a page or signature number following a lowercase [letter] - e.g. '[a] p. 66'-signifies that the edition agreed with Locke's correction of Baxter's Horace. In some places, an edition agreed with Locke's correction but disagreed with Baxter in a different respect, such as punctuation or spelling. Where this has happened, the disagreement has been enclosed within \{braces\}. A page or signature number following an uppercase [letter] - e.g. ' $[A]$ p. 77 ' - signifies that the edition agreed with Locke's orthography and printed 'urgere' and its conjugations.

${ }^{17}$ For a discussion of the Outram-Gataker sale see T. A. Birrell, 'John Locke at three English book auctions: December 1681 to June 1682', in id., Aspects of book culture in early modern England, ed. Jos Blom (Farnham, 2013), pp. 43-62. ESTC lists no editions of Bond's Horace from 1666, suggesting that Locke derived ' 66 ' from the Catalogus' listing rather than his consultation of the purchased copy. Extant editions from 1606 and 1660 raise the possibility that the auctioneer substituted a ' 6 ' for a ' 0 '. 
Instances where an edition printed 'urguere' and its conjugations have been marked in bold-e.g. ' $[A]$ p. 77: 'urguet'. Note that error [c] cannot be compared, since it is an error in Baxter's own gloss and not a controvertible transcription of Horace's text.

Gonville \& Caius College, Cambridge 